\title{
New Method for Spectrophotometric Determination of Lisinopril in Pure Form and in Pharmaceutical Formulations
}

\section{Mohammad Shraitah and Malek MS Okdeh*}

Department of Chemistry, Techreen University, Lattakia, Syria

\begin{abstract}
An accurate, simple, fast and cheap spectrophotometric method has been developed for the determination of lisinopril in pharmaceutical pure and dosage forms. The method is based on the reaction of Alizarin with primary amine present in the lisinopril in the presence of $80 \%$ ethyl alcohol. This reaction produces a complex Red colored product which absorbs maximally at $434 \mathrm{~nm}$. Beer's law was obeyed in the range of $4.415-300.23 \mu \mathrm{g} / \mathrm{mL}$ with molar absorptivity of $1.619 \times 10^{3} \mathrm{~L} \mathrm{~mole}^{-1} \mathrm{~cm}^{-1}$ Sandell's sensitivity $0.272 \mu \mathrm{g} . \mathrm{cm}^{-2}$. The effects of variables such as temperature, heating time, concentration of color producing reagent, and stability of color were investigated to optimize the procedure. The results are validated statistically. The proposed method was applied to commercially available tablets, and the results were Pharmaceutical formulations.
\end{abstract}

Keywords: Lisinopril; Alizarin; Spectrophotometry

\section{Introduction}

Lisinopril (S)-1-[N-[1-(ethoxycarbonyl)-3 phenylpropy1]-Lalanyl]-L-proline are Angiotensin-Converting Enzyme (ACE) has been widely used for the treatment of hypertension and heart failure. The analytical profiles of the drugs have been reviewed [1,2]. Enalapril maleate has been assayed by spectrophotometric [3-7], potentiometric [8,9], HPLC [10-14] and ${ }^{1} \mathrm{H}-\mathrm{NMR}$ [15] methods. In tablets, lisinopril dihydrate has been determined by GC $[16,17]$, spectrophotometric [18-21], colorimetric and fluorimetric [17] procedures. Capillary electrophoresis has been used to separate closely related ACE inhibitors and to quantities them in their pharmaceutical preparations $[22,23]$ and stripping voltammetric method [24]. Quite a few researchers have dealt with the development of methods that quantify lisinopril in biological media. Methods that include Polarographic, spectrophotometric $[25,26]$ even today because of its inherent simplicity, sensitivity, visible spectrophotometry is the technique of choice selectivity, accuracy, precision and cost-effectiveness. LNP in pharmaceuticals has been assayed based on reaction with $\mathrm{N}$-bromosuccinimide and the charge transfer complexation reaction [27].

Sodium hypochlorite-phenyl hydrazine [7], 1-fluoro-2,4dinitrobenzene [28] and ascorbic acid [29]. Most of these methods employ organic solvents as reaction medium, require longer heating times, use expensive reagents, and/or are less sensitive (Table 1). Of the various regents used in the assay of LNP in pharmaceuticals, ninhydrin has been employed by quite a few researchers. For example, Rehman et al. [29] used ninhydrin in DMF medium for kinetic spectrophotometric determination of LNP by initial rate and fixedtime procedures. Both methods showed linear response over $50 \mu \mathrm{g} /$ $\mathrm{mL}$ LNP. The reagent in the same organic solvent medium (DMF) but involving heating was used by Raza et al. [30] to quantify LNP in 10-150 $\mu \mathrm{g} / \mathrm{mL}$ range. Rajashekaran and Udayavani [31] assayed LNP in the 10$40 \mu \mathrm{g} / \mathrm{mL}$ range by measuring the coloured product formed between ninhydrin and LNP in acetone medium at elevated temperature. The common feature of all the three methods using ninhydrin [29-31] is the use of organic solvent as the reaction medium which quite often is undesirable.

\section{Experimental}

\section{Reagents and apparatus} India)

Lisinopril (100.03\% pure reference substance, produced by Lupin,

-Stock solution ( $1 \mathrm{mg} / \mathrm{mL}$ ): $100 \mathrm{mg}$ lisinopril was dissolved in $20 \%$ $\mathrm{ml}$ water and $80 \%$ ethyl alcohol in a $100 \mathrm{~mL}$ volumetric flask.
-Stock solution ( $1 \mathrm{mg} / \mathrm{mL}$ ): $100 \mathrm{mg}$ Alizarin was dissolved in 20\% $\mathrm{ml}$ water and $80 \%$ ethyl alcohol in a $100 \mathrm{~mL}$ volumetric flask.

\section{Buffer solution}

Different buffer Solution used $0.2 \mathrm{M}$ Acetate buffer, $0.2 \mathrm{M}$ Ammonium buffer, $0.2 \mathrm{M}$ borate buffer and $0.2 \mathrm{M}(\mathrm{pH}=2.0-12.0)$ universal Britton buffer solution.

$-\mathrm{FeCl}_{3}$ Solution

Ferric chloride solution $1 \%$ dissolved in alkaline weak medium from-Ammonium hydroxide $\left(1.0 \times 10^{-4} \mathrm{M}\right)$.

-Analytical balance

-UV-Vis Spectrophotometer Model SP3000 OpTMA from Korea

\section{Principle of the method}

We studied the best volume and concentration of the Lisinopril, Alizarin, universal Britton buffer at $\mathrm{pH}=8.0$, Ferric chloride solutions on the formation red complex, and added $0.4 \mathrm{ml}$ Ferric chloride solution $1 \%$ dissolved in weak $\mathrm{NH}_{4} \mathrm{OH}$ determined at $\lambda_{\max }=434 \mathrm{~nm}$.

\section{Lisinopril-Alizarin method}

To different aliquots of Alizarin solution corresponding to 0.5-7.0 $\mathrm{ml}^{-1}$ was transferred into a series of $10 \mathrm{ml}$ volumetric flasks. $0.5-6.0 \mathrm{ml}$ of Lisinopril solution and Universal buffer Britton solution $\mathrm{pH}=8.0$ were added to each flask diluted to volume with $1: 2 \mathrm{H}_{2} \mathrm{O}: \mathrm{C}_{2} \mathrm{H}_{5} \mathrm{OH}$. The solution was heated in a water bath at $40 \pm 1^{\circ} \mathrm{C}(5 \mathrm{~min})$, respectively. The mixtures were cooled and the volume was completed to $10 \mathrm{~mL}$ with mixture solvent measured after 10 min of mixing against reagent blank [32,33].

\section{Analysis of pharmaceutical formulations}

20 tablets were accurately weighted finely powdered and dissolved

${ }^{*}$ Corresponding author: Malek MS Okdeh, Department of Chemistry, Techreen University, Lattakia, Syria, Tel: +9634135245; E-mail: dr.malekokdeh@yahoo.com

Received November 26, 2015; Accepted January 04, 2016; Published January 08, 2016

Citation: Shraitah M, Okdeh MMS (2016) New Method for Spectrophotometric Determination of Lisinopril in Pure Form and in Pharmaceutical Formulations. Mod Chem appl 4: 172. doi:10.4172/2329-6798.1000172

Copyright: $\odot 2016$ Shraitah M, et al. This is an open-access article distributed under the terms of the Creative Commons Attribution License, which permits unrestricted use, distribution, and reproduction in any medium, provided the original author and source are credited. 
into sufficient volume of mixture solvent. The mixture was stirred well and filtered through Whatman filter paper No. 42 and the filtrate was diluted with mixture solvent added universal Britton buffer $\mathrm{pH}=8.0$ and $0.4 \mathrm{ml} \mathrm{FeCl}_{3} 1 \%$ in alkali weak medium from $\mathrm{NH}_{4} \mathrm{OH}\left(1 \times 10^{-4} \mathrm{M}\right)$ in $10 \mathrm{ml}$ volumetric flask. The mixtures were cooled and the volume was completed to $10 \mathrm{~mL}$ with mixture solvent and absorbance was measured after 7 min of mixing against reagent blank [34].

\section{Results and Discussion}

Preliminary investigations have been shown that Lisinopril react with Alizarin in buffer Britton solution $0.1 \mathrm{M}$ at $\mathrm{pH}=8.0$ in presence catalytic reagent as ferric chloride $0.40 \mathrm{ml}$ with Concentration $(1 \times$ $10^{-3} \mathrm{M}$ ) to give red coloured complex which absorbs at $\lambda_{\max }=434 \mathrm{~nm}$ as shown in Figure 1 [30,35].

The optimum reaction conditions for quantitative determination of the ion pair complexes were established via number of preliminary experiments. Several parameters such as amount of buffer added, reagent concentration, temperature, heating time, sequence of addition and color stability. It was observed that complete color development was attained at $40 \pm 1^{\circ} \mathrm{C}(7 \mathrm{~min})$ (Figure 2). The effect of Alizarin concentration on the color development was investigated $3 \mathrm{ml}$ of Alizarin reagent produced maximum color intensity (Figure 3) [36].

\section{Stoichiometric relationship}

A series of solutions were prepared by mixing equimolecular proportions while keeping the total molar concentration constant in all cases and reagent concentration within range $100-800 \mu \mathrm{M}$ or complex Lisinopril-Alizarin (LNP-ALZ) solutions changed the volume of Lisinopril (VLNP) and Volume of Alizarin was kept constant (VALZ) within range from $(1.0-8.0 \mathrm{ml})$ and the total volume was kept constant in all these series are equal to (LNP+ALZ=9.0 ml) The absorbance values were then plotted against the mole fraction (VLNP)/ (VLNP+VAZ) or VAZ/(VLNP+VAZ). The stoichiometry of the reaction between Lisinopril and Alizarin at selected conditions (Figure 4) was observed. The stoichiometry of the reaction between drugs and at the selected conditions was established by the molar ratio method. In this method $0.4 \mathrm{~mL}$ of $1 \% \mathrm{FeCl}_{3}$ in alkali weak from $\mathrm{NH}_{4} \mathrm{OH}$ medium is and $0.05 \mathrm{ml}$ buffer Universal Britton $\mathrm{pH}=8.0 \mathrm{kept}$ constant and variable concentrations of drugs $\left(5.0 \times 10^{-4} \mathrm{M}\right)$ were added [34,35]. The absorbance was measured at $\lambda_{\max }$ against blank solution prepared in the same manner. The absorbance values were then plotted against the molar ratio [Alizarine]/[Lisinopril] (Figure 5).

Developed color was stable up to 72 hours which was considered sufficient time for an analysis (Figure 6). Beer's law was obeyed in the range of $4.415-300.23 \mu \mathrm{g} / \mathrm{ml}$. More than $99 \%$ recover of Lisinopril was obtained in the presence of possible excipients and ingredient in lisinopril formulations (Tables 1 and 2) [35].

Optical characteristics and statistical data for the regression equation of the proposed method are given in Table 1. Commercial formulation was successfully analyzed for the lisinopril by the proposed method and the results are compared with reference method (20) (Table 3) did not exceed the theoretical values, which indicates the absence of any difference between the methods compared. The proposed method gives good results for lisinopril in pure and pharmaceutical formulations $[35,36]$.

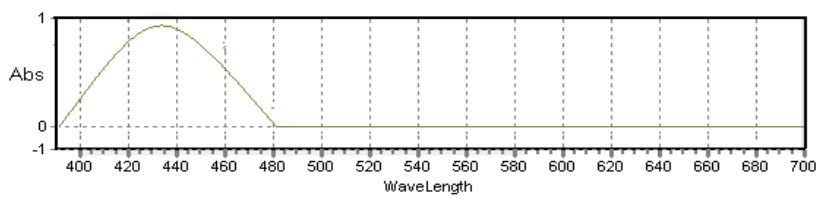

Figure 1: Absorption spectrum of lisinopril-alizarin formation.

\section{Conclusion}

The proposed method for the estimation of Lisinopril using

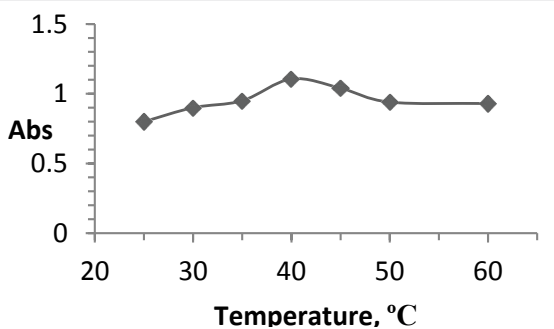

Figure 2: Effect of temperature on the color development..

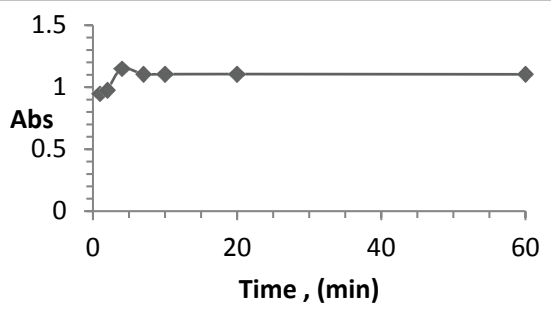

Figure 3: Effect of heating time on color intensity

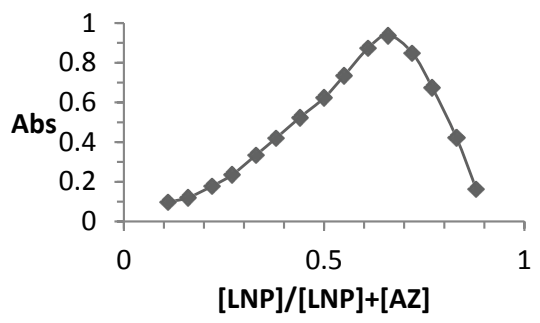

Figure 4: The mole fraction of (VLNP)/(VLNP+VAZ).

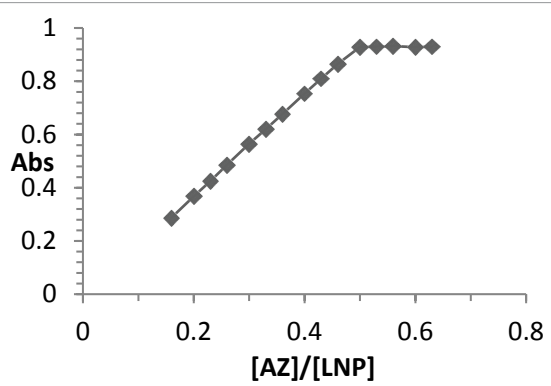

Figure 5: The molar ratio of [Alizarin]/[Lisinopril].

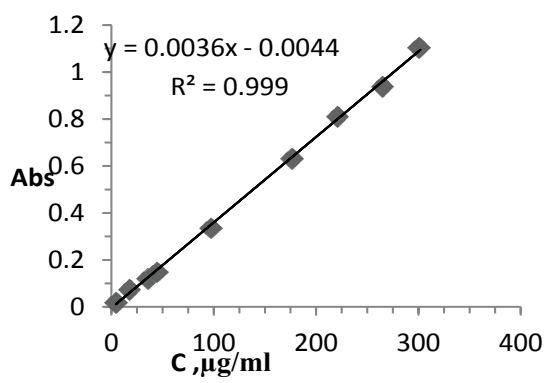

Figure 6: The molar ratio of [Alizarin]/[Lisinopril] 
Citation: Shraitah M, Okdeh MMS (2016) New Method for Spectrophotometric Determination of Lisinopril in Pure Form and in Pharmaceutical Formulations. Mod Chem appl 4: 172. doi:10.4172/2329-6798.1000172

Page 3 of 4

\begin{tabular}{|c|c|c|c|c|c|c|}
\hline $\begin{array}{l}\text { Drug } \\
\text { samples }(\mu \mathrm{g} / \mathrm{ml}) \\
\text { Amount taken }\end{array}$ & $\begin{array}{l}\text { Found } \\
(\mu \mathrm{g} / \mathrm{ml})\end{array}$ & Stander devation SD & R.S.D \% & $\begin{array}{l}\text { Detection limit } \\
(\mu \mathrm{g} / \mathrm{ml})\end{array}$ & $\begin{array}{l}\text { Analytical Error SD/ } \\
(\mathrm{n})^{1 / 2}\end{array}$ & $\begin{array}{l}\text { Relative Recovery } \\
\text { (\% ) R }\end{array}$ \\
\hline 4.415 & 4.503 & 0.155 & 3.44 & $4.503 \pm 0.191$ & 0.069 & 101.99 \\
\hline 17.666 & 17.723 & 0.150 & 0.84 & $17.723 \pm 0.185$ & 0.067 & 100.32 \\
\hline 35.321 & 35.414 & 0.164 & 0.46 & $35.414 \pm 0.202$ & 0.073 & 100.26 \\
\hline 44.152 & 44.240 & 0.174 & 0.39 & $44.240 \pm 0.213$ & 0.077 & 100.19 \\
\hline 97.134 & 97.276 & 0.217 & 0.22 & $97.276 \pm 0.269$ & 0.097 & 100.14 \\
\hline 176.608 & 176.801 & 0.272 & 0.15 & $176.801 \pm 0.335$ & 0.121 & 100.10 \\
\hline 220.760 & 220.602 & 0.281 & 0.12 & $220.602 \pm 0.347$ & 0.125 & 99.92 \\
\hline 264.912 & 264.802 & 0.275 & 0.10 & $264.802 \pm 0.338$ & 0.122 & 99.95 \\
\hline 300.233 & 300.116 & 0.277 & 0.09 & $300.116 \pm 0.341$ & 0.123 & 99.96 \\
\hline
\end{tabular}

Five independent analyses

Table 1: Test of precision and accuracy of the proposed method.

\begin{tabular}{|c|c|}
\hline Parameter & Value \\
\hline$\lambda \max$ & $432 \mathrm{~nm}$ \\
\hline Beer's law limit $(\mu \mathrm{g} / \mathrm{mL})$ & $4.415-300.233$ \\
\hline Molar abs orptivity $\left(\mathrm{L} \mathrm{mole}^{-1} \mathrm{~cm}^{-1}\right)$ & $1.619 \times 10^{3}$ \\
\hline Sandell's s ens itivity $(\mu \mathrm{g} / \mathrm{mL}$ per $0.001 \mathrm{~A})$ & 0.273 \\
\hline \multicolumn{2}{|c|}{ Regres $\mathrm{s}$ ion equation $\left(\mathrm{Y}^{*}\right)$} \\
\hline Slope (m) & 0.003 \\
\hline Intercept (c) & 0.004 \\
\hline Correlation coefficient & 0.999 \\
\hline Relative Standard Deviation** & 3.44 \\
\hline Limit of Detection $(\mu \mathrm{g} / \mathrm{mL})^{\star \star *}$ & 2.08 \\
\hline Limit of quantitation $(\mu \mathrm{g} / \mathrm{ml})$ & 6.94 \\
\hline
\end{tabular}

${ }^{*} \mathrm{Y}=\mathrm{mx}+\mathrm{C}$; Where $\mathrm{x}$ is the concentration of analyte $(\mu \mathrm{g} / \mathrm{mL})$ and $\mathrm{Y}$ is absorbance unit; **: Calculated from six determinations; ${ }^{* *}$ : Calculated as per ICH guidelines Table 2: Optical characteristics and statistical data for the regression equation of the proposed method.

\begin{tabular}{|c|c|c|c|c|c|c|c|c|}
\hline S. No. & Reagents & $\lambda_{\max }$ & $\begin{array}{l}\text { Linear } \\
\text { Dynamic } \\
\mu \mathrm{g} \mathrm{mL}-1\end{array}$ & Reaction time & $\begin{array}{l}\text { Molar absorptivity } \\
(\varepsilon) \mathrm{Lmol}^{-1} \mathbf{c m}^{-1}\end{array}$ & LOD & LQP & References \\
\hline 1 & Alizarine & 432 & $4.415-300.23$ & $7 \mathrm{~min}$ at $40^{\circ} \mathrm{C}$ & $1.619 \times 10^{3}$ & - & - & This Work \\
\hline 2 & Dichlone & 580 & $40-120$ & 10 min at rt & $2.6 \times 10^{3}$ & - & - & {$[20]$} \\
\hline 3 & $\begin{array}{l}\text { Acetylacetone + } \\
\text { Formaldehyde }\end{array}$ & 356 & $6.0-42.0$ & $\begin{array}{l}10 \mathrm{~min} \\
\text { at } \\
100^{\circ} \mathrm{C}\end{array}$ & $9.62 \times 10^{3}$ & - & - & {$[20]$} \\
\hline 4 & 2,4- dinitrofluorobenzene & 400 & $8.0-120.0$ & $30 \mathrm{~min}$ at $80^{\circ} \mathrm{C}$ & - & 1.16 & 3.87 & [28] \\
\hline 5 & Phenylhydraizine & 362 & $40-200$ & $\begin{array}{l}20 \mathrm{~min} \\
\text { at } 85^{\circ} \mathrm{C}\end{array}$ & - & - & - & [8] \\
\hline 6 & $\begin{array}{l}\text { 7-chloro-4-nitrobenzo- } \\
\text { 2-oxa-1, 3-diazole }\end{array}$ & 470 & $20.0-560$ & $30 \mathrm{~min}$ at $70^{\circ} \mathrm{C}$ & - & 0.27 & 0.891 & {$[36]$} \\
\hline 7 & Ninhydrin & 410 & $10-40$ & $\begin{array}{l}10 \mathrm{~min} \text { at } \\
100^{\circ} \mathrm{C}\end{array}$ & $1.845 \times 10^{3}$ & - & - & [31] \\
\hline 8 & As corbic acid method & 530 & $5-50$ & $\begin{array}{l}15 \mathrm{~min} \\
\text { at } \\
100^{\circ} \mathrm{C}\end{array}$ & $4.548 \times 10^{3}$ & 0.349 & 1.152 & [29] \\
\hline 9 & Ninhydin kinetic method & & & & & & & \\
\hline a) & Initial rate method & 595 & $10-50$ & $\begin{array}{l}\text { Immed } \\
\text { iately after mixing the } \\
\text { reagent at rt }\end{array}$ & - & 0.118 & 0.389 & [29] \\
\hline b) & Rate cons tant method & 595 & $10-40$ & -do- & - & 2.839 & 9.369 & [29] \\
\hline c) & Fixed time method & 595 & $5-50$ & $\begin{array}{l}10 \mathrm{~min} \\
\text { at rt }\end{array}$ & $4.70 \times 10^{3}$ & 1.03 & 3.399 & [29] \\
\hline
\end{tabular}

rt: Room temperature

Table 3: Comparision of the proposed methods with existing spectrophotometric methods for the assay of lisinopril in pharmaceutical formulations.

Alizarin is advantages over many of the reported methods. The methods are rapid, simple and have good sensitivity and accuracy. Proposed method makes use of simple reagent, which an ordinary analytical laboratory can afford. The high recovery percentage and low relative Standard deviations reflect the high accuracy and precision of the proposed method. The method are easy, applicable to a wide range of concentration, besides being less time consuming and depend on simple reagent which are available, thus offering economic and acceptable method for the routine determination of Lisinopril in its formulations. 
Citation: Shraitah M, Okdeh MMS (2016) New Method for Spectrophotometric Determination of Lisinopril in Pure Form and in Pharmaceutical Formulations. Mod Chem appl 4: 172. doi:10.4172/2329-6798.1000172

\section{References}

1. Lancaster SG, Todd PA (1988) Lisinopril. A preliminary review of its pharmacodynamic and pharmacokinetic properties, and therapeutic use in hypertension and congestive heart failure. Drugs 35: 646-669.

2. The United States Pharmacopoeia (2000) 24th Revision. Asian Edition. United States Pharmacopoeial Convention, Inc., Twinbrook Parkway, Rockville, MD, USA.

3. Kato T (1985) Flow-injection spectrophotometric determination of enalapril in pharmaceuticals with bromothymol blue. Anal Chim Acta 175: 339-344.

4. Blaih SM, Abdine HH, El-Yazbi FA, Shaalan RA (2000) Spectrophotometric determination of enalapril maleate and ramipril in dosage forms. Spectrosc Let 33: 91-102.

5. Dhake AS, Kasture VS, Sayed MR (2002) Spectrophotometric method for simultaneous estimation of amlodipine besylate and enalpril maleate intablets. Indian Drugs 39: 14-17

6. Ayad MM, Shalaby AA, Abdellatef HE, Hosny MM (2002) Spectrophotometric and AAS determination of ramipril and enalapril through ternary complex formation. J Pharm Biomed Anal 28: 311-321.

7. Razen J, Senica D (2001) Concentration of lisinopril purified by liquid chromatography-A comparison between reverse osmosis and evaporation. Acta Chim Slov 48: 597-612.

8. El-Gindy A, Ashour A, Abdel-Fattah L, Shabana MM (2001) Spectrophotometric and HPTLC-densitometric determination of lisinopril and hydrochlorothiazide in binary mixtures. J Pharm Biomed Anal 25: 923-931.

9. Leis HJ, Fauler G, Raspotnig G, Windischhofer W (1999) An improved method for the measurement of the angiotensin-converting enzyme inhibitor lisinopril in human plasma by stable isotope dilution gas chromatography/negative ion chemical ionization mass spectrometry. Rapid Commun Mass Spectrom 13 650-653.

10. Leis HJ, Fauler G, Raspotnig G, Windischhofer W (1998) Quantitative determination of the angiotensin-converting enzyme inhibitor lisinopril in human plasma by stable isotope dilution gas chromatography/negative ion chemical ionization mass spectrometry. Rapid Commun Mass Spectrom 12: 1591-1594.

11. Quin X, Nquen DT, Dominic P (1993) Separation of lisinopril and its RSS diastereoisomer by miceller electrokinetic chromatography. J Liquid Chromatogr 16: $3713-3734$

12. Hillaret S, VandenBopscha W (2000) Optimization of capillary electrophoretic separation of several inhibitors of the angiotensin-converting enzyme. J Chromatogr A 895: 33-42.

13. Gotti R, Andrisano V, Cavrini V, Bertucci C, Furlanetto S (2000) Analysis of ACE-inhibitors by CE using alkylsulfonic additives. J Pharm Biomed Anal 22: 423-431.

14. Rajasekaran A, Murugesan S (2001) Polarographic studies of Lisinopril. Asian J Chem 13: 1245-1246.

15. Ouyang J, Baeyens WR, Delanghe J, Van der Weken G, Calokerinos AC (1998) Cerium (IV)-based chemiluminescence analysis of hydrochlorothiazide. Talanta 46: 961-968.

16. Worland PJ, Jarrott B (1986) Radioimmunoassay for the quantitation of lisinopril and enalaprilat. J Pharm Sci 75: 512-516.

17. Yuan AS, Gilbert JD (1996) Time-resolved fluoroimmunoassay for the determination of lisinopril and enalapril at in human serum. J Pharm Biomed Anal 14: 773-781.

18. Atmaca S, Tatar S, Iskender G (1994) Spectrophotometric determination of lisinopril in tablets. Acta Pharm Turc 36: 13-16.

19. Iskender G, Yarenei B (1995) A spectrophotometric method for the determination of lisinopril in tablets. Acta Pharm Turc 37: 5-8.

20. El-Yazbi FA Abdine HH, Shaalan RA (1999) Spectrophotometric and spectrofluorometric methods for the assay of lisinopril in single and multicomponent pharmaceutical dosage forms. J Pharm Biomed Anal 19: 819-827.

21. El-Emam AA, Hansen SH, Moustafa MA, El-Ashry SM, El-Sherbiny DT (2004) Determination of lisinopril in dosage forms and spiked human plasma through derivatization with 7-chloro-4-nitrobenzo-2-oxa-1,3-diazole (NBD-Cl) followed by spectrophotometry or HPLC with fluorimetric detection. J Pharm Biomed Anal 34: 35-44.
22. Aruna DP, Mallikarjuna RGPV, Krishna PKMM, Sastry CSP (2003) Four simple spectrophotometric determination of lisinopril in pure state and in tablets. Indian J Pharm Sci 65: 296-299.

23. Ozer D, Senel H (1999) Determination of lisinopril from pharmaceutical preparations by derivative UV spectrophotometry. J Pharm Biomed Anal 21 : 691-695.

24. Prasad CVN, Saha RN, Parimoo P (1999) Simultaneous Determination of Amlodipine-Enalapril Maleate and Amlodipine-Lisinopril in Combined Table Preparations by Derivative Spectrophotometry. Pharm Pharmacol Commun 5 : 383-388.

25. Erk N (1998) Combined study of the ratio spectra derivative spectrophotometry, derivative spectrophotometry and Vierordt's method applied to the analysis of lisinopril and hydrochlorothiazide in tablets. Spectrosc Lett 31: 633-645.

26. Melby LR, Harder RJ, Hertler WR, Mahler W, Benson RE, et al. (1962) Substituted Quinodimethans. II. Anion-radical Derivatives and Complexes of 7,7,8,8-Tetracyanoquinodimethan. J Am Chem Soc 84: 3374-3387.

27. Rahman N, Anwar N, Kashif M (2005) Application of pi-acceptors to the spectrophotometric determination of lisinopril in commercial dosage forms. Farmaco 60: 605-611.

28. Paraskevas G, Atta-Politou J, Koupparis M (2002) Spectrophotometric determination of lisinopril in tablets using 1-fluoro-2,4-dinitrobenzene reagent J Pharm Biomed Anal 29: 865-872.

29. Rehman N, Singh M, Hoda MN (2005) Optimized and validated spectrophotometric methods for the determination of lisinopril in pharmaceutical formulations using ninhydrin and ascorbic acid. J Braz Chem Soc 16: 10011009 .

30. Raza A, Ansari TM, Rehman AU (2005) Spectrophotometric determination of lisinopril in pure and pharmaceutical formulations. J Chin Chem Soc 52: 10551059.

31. Rajasekaran A, Udayavani S (2001) Spectrophotometric determination of lisinopril in pharmaceutical formulations. J Indian Chem Soc 78: 485-486.

32. European Pharmacopoeia (2007) European Directorate for Quality medicine and health care. Monograph number 1120. p: 2277.

33. Basavaiah K, Tharpa K, Hiriyanna SG, Vinay KB (2009) Spectrophotometric determination of lisinopril in pharmaceuticals using ninhydrin-a modified approach. J Food \& Drug Anal 17: 93-99.

34. Rahman N, Haque SM (2008) Optimized and validated spectrophotometric methods for the determination of enalapril maleate in commercial dosage forms. Anal Chem Insights 3: 31-43.

35. Rahman N, Siddiqui MR, Azmi SNH (2007) Spectrophotometric determination of lisinopril in commercial dosage forms using $\mathrm{N}$-bromosuccinimide and chloranil. Chem Anal (Warsaw) 52: 465-480.

36. Shama SA, Amin AS, Omara H (2011) Spectrophotometric Microdetermination of Some Antihypertensive Drugs in Pure Form and in Pharmaceutical Formulations. J Chil Chem Soc 56: 566-570. 